\title{
Revisiting stepwise ocean oxygenation with authigenic Ba enrichments in marine
}

\section{mudrocks}

Guang-Yi Wei ${ }^{1 *}$, Hong-Fei Ling ${ }^{1}$, Simon V. Hohl' ${ }^{2}$, Graham A. Shields ${ }^{3}$, Tao Yang ${ }^{1}$, Yi-Bo

$$
\text { Lin }^{1} \text {, Feifei Zhang }{ }^{1}
$$

${ }^{1}$ State Key Laboratory for Mineral Deposits Research, School of Earth Sciences and Engineering, Nanjing University, Nanjing 210023, China

\section{${ }^{2}$ State Key Laboratory of Marine Geology, School of Ocean and Earth Sciences, Tongji}

University, Shanghai 200092, China

${ }^{3}$ Department of Earth Sciences, University College London, Gower Street, London WC1E 6BT, U.K.

\section{*Email: G.-Y. Wei (guangyiwei@nju.edu.cn)}

\section{Abstract}

There are still debates around the extent of global ocean oxygenation, particularly from the late Neoproterozoic to the early Paleozoic, based on analyses of various geochemical indices. Here, we present a temporal trend in excess barium $\left(\mathrm{Ba}_{\text {excess }}\right)$ contents in marine organic-rich mudrocks (ORMs) to provide an independent constraint on global ocean redox evolution. No remarkable $\mathrm{Ba}_{\text {excess }}$ enrichments in Precambrian (>ca. $541 \mathrm{Ma}$ ) ORMs suggest limited authigenic Ba deposits in oxygen- and sulfate-depleted oceans. By contrast, in the Paleozoic, particularly the early Cambrian, ORMs are marked by significant $\mathrm{Ba}_{\text {excess }}$ enrichments, corresponding to substantial increases in marine sulfate reservoir and oxygenation level. Analogous to modern sediments, the Mesozoic and Cenozoic ORMs exhibit no prominent $\mathrm{Ba}_{\text {excess }}$ enrichments due to the subsequent exhaustion of dissolved $\mathrm{Ba}$. The progressive decline in marine dissolved Ba concentrations coincides with elevated marine sulfate levels associated with global ocean oxygenation. Further, unlike Mo, U, Re abundances, significant $\mathrm{Ba}_{\text {excess }}$ 
enrichments in ORMs indicate that the overall ocean oxygenation level in the early Paleozoic was substantially lower than present level.

\section{Introduction}

The Earth's 4.5-billion-year history is characterized by a stepwise increase in atmospheric and oceanic oxygen levels with two major steps recognized in the geologic record: the 'Great Oxidation Event' (GOE) between 2.4 and 2.1 Ga; and the 'Neoproterozoic Oxidation Event' (NOE) between 0.8 and 0.55 Ga (Holland, 2006; Lyons et al., 2014; Knoll et al., 2017). Multiple redox proxies have been used to track the long-term redox evolution of Earth's atmosphere and ocean (see reviews in Canfield, 2005; Och and Shields-Zhou, 2012;Tostevin and Mills, 2020), among which the concentrations of redox-sensitive metals in marine organic-rich mudrocks provided insights into temporal changes in marine redox states (Robbins et al., 2016; Algeo and $\mathrm{Li}, 2020)$. The enrichments of Mo, $\mathrm{U}, \mathrm{Re}, \mathrm{Cr}$ in marine organic-rich mudrocks (ORMs, defined by having a total organic carbon content of $>0.4 \mathrm{wt} \%$ ) are generally indicative of evolutionary history of global seafloor redox, based on the principle that the contents of these elements in ORMs have been primarily determined by their concentrations in the ocean associated with global marine redox states (Scott et al., 2008; Partin et al., 2013; Reinhard et al., 2013; Sheen et al., 2018). Secular changes in Mo, U, and Re concentrations in ORMs consistently supported the stepwise increases in marine oxygen levels throughout Earth's history (Fig. 1) (Scott et al., 2008; Partin et al., 2013; Sheen et al., 2018). Significantly elevated Mo, U, and Re enrichments through the NOE highlight that marine Mo, U, and Re reservoirs were potentially comparable to those in the modern ocean as a result of progressive ocean oxygenation. However, the sizes of marine Mo, $\mathrm{U}$, and Re reservoirs may not be linearly related to the dissolved $\mathrm{O}_{2}$ concentration 
of global seawater. Rises to current magnitudes of these marine dissolved metal reservoirs correspond to limited global anoxic or euxinic seafloor (Reinhard et al., 2013; Partin et al., 2013; Sheen et al., 2018), but does not require seawater dissolved $\mathrm{O}_{2}$ concentrations close to that of the modern ocean. In this view, Mo, $U$, and Re enrichments in ORMs only provide a maximum constraint on the extents of global anoxic or euxinic seafloor. More constraints on the extent of global ocean oxygenation cannot be directly acquired based on these metal proxies. For modern fully oxidized oceanic basins, with Ba-limited conditions, excess barium $\left(\mathrm{Ba}_{\mathrm{excess}}\right)$ accumulations in marine sediments are commonly considered linked to the formation of $\mathrm{BaSO}_{4}$-supersaturated' microenvironments' in organic matter linked to shallow-marine export productivity (e.g., Bishop, 1988; Dymond et al., 1992; Paytan and Griffith, 2007; Martinez-Ruiz et al., 2019). However, more systemic analyses of modern marine sediments deposited in different redox environments challenged the use of Baexcess as a reliable proxy for paleo-productivity on a more global scale (Schoepfer et al., 2015). In particular, predominantly $\mathrm{O}_{2}$-deficient oceans of the Precambrian may have had a more extensive dissolved Ba reservoir in deep waters (cf. Falkner et al., 1993; Crockford et al., 2019). Thus, the water column's sulfate contents, rather than Ba concentrations, may have played a firstorder control in $\mathrm{Ba}_{\text {excess }}$ accumulation in ancient marine sediments (Torres et al., 1996). Although $\mathrm{Ba}$ is not a redox-sensitive element, the removal of $\mathrm{Ba}$ from the water column is intrinsically linked to marine sulfate levels, associated with global oceanic redox states and pyrite burial fluxes. In this view, Ba enrichments in ancient sediments depend on co-evolution of dissolved $\mathrm{Ba}$ and sulfate reservoirs in the ancient oceans. In this study, we present $\mathrm{Ba}$ concentrations of ORMs from the Archean to the modern times, aiming to provide new insights 
into the extent of global ocean oxygenation throughout the Earth's history. Combining with the estimated marine sulfate concentrations, we use authigenic Ba concentrations in ORMs to reconstruct the long-term evolution of the marine dissolved Ba reservoir, and further constrain the global ocean oxygenation level in the critical geological periods.

\section{Analytical methods}

New major and trace element data in this study were analyzed using Thermo Finnigan Element XR ICP-MS at the State Key Laboratory for Mineral Deposits Research, Nanjing University. The long-term reproducibility of the measurements was better than $5 \%$ in this study, based on duplicated analyses of IAPSO seawater and BHVO-2 standards. We also compiled a literature database of $\mathrm{Ba}$ concentrations and associated $\mathrm{Al}$ and $\mathrm{TOC}$ contents in ORMs through geological time. Since barite ore-bearing rocks associated with local hydrothermal or burial diagenetic processes can exhibit extreme Ba enrichments non-related to global oceanic dissolved Ba concentrations, they were excluded from our database and not discussed further on. We also chose the typical samples in the early Cambrian for SEM (scanning electron microscopy) observations, in order to better constrain the origin of particulate $\mathrm{Ba}$ in ancient ORMs (Figs. DR2, DR3).

Authigenic Ba concentrations of analyzed and literature marine sediments (i.e., nondetrital particulate $\mathrm{Ba}$, defined as $\mathrm{Ba}_{\text {excess }}$ ) were calculated using the following equations:

$[B a]_{\text {detritus }}=\left[\frac{B a}{A l}\right]_{\text {detritus }} \cdot[A l]_{\text {bulk }}$

$[B a]_{\text {excess }}=[B a]_{\text {bulk }}-[B a]_{\text {detritus }}$ 
The $\mathrm{Ba} / \mathrm{Al}$ ratios of the detrital component were derived from the average upper continental crust $\left(\mathrm{Al}_{\mathrm{UCC}}=8.15 \mathrm{wt} \%, \mathrm{Ba}_{\mathrm{UCC}}=624 \mathrm{ppm}\right)\left(\right.$ Rudnick and Gao, 2014). Temporal trends in $\mathrm{Ba}_{\text {excess }}$ enrichment in ORMs through the geological time are presented in Fig. 2.

\section{Results and Discussion}

Dissolved $\mathrm{Ba}$ in the modern oceans is commonly sourced from continental weathering, along with a relatively small flux of hydrothermal fluids, and scavenged by particulate $\mathrm{Ba}$ (i.e., discrete $\mu \mathrm{m}$-sized barite) and its subsequent burial (Dickens et al., 2003). Modern pelagic sediments typically have significantly low $\mathrm{Ba}_{\text {excess }}$ concentrations due to low dissolved $\mathrm{Ba}$ concentrations and $\mathrm{BaSO}_{4}$-undersaturated conditions of deep seawater (Bridgestock et al., 2018). Given the high sulfate concentration $(\sim 29 \mathrm{mM})$ in modern fully oxidized oceans, particulate $\mathrm{Ba}$ accumulations in the sediments are dominated by the limited dissolved $\mathrm{Ba}$ availability in the water column $(<\sim 100 \mathrm{nM})$ (Martinez-Ruiz et al., 2019). Analogous to modern marine sediments, the Cenozoic and Mesozoic ORMs consistently show low Ba $a_{\text {excess }}$ concentrations $(<\sim 3500 \mathrm{ppm})$, demonstrating presumably $\mathrm{BaSO}_{4}$-undersaturated conditions of the coeval seawater. By contrast, the Paleozoic ORMs are characterized by significant $\mathrm{Ba}_{\text {excess }}$ enrichments (up to 10000-20000 ppm), suggesting much more Ba traps from the water column compared to modern ocean. The $\mathrm{Ba}_{\text {excess }}$ concentrations of the Precambrian ORMs $(>$ ca. 541 Ma) are overall low ( $<4000 \mathrm{ppm})$, except for several high values around the Paleoproterozoic (ca. $1.8 \mathrm{Ga}$ ) (up to $10000 \mathrm{ppm}$ ). For Neoproterozoic and Paleozoic ORMs, no appreciable relationships of $\mathrm{Ba}_{\text {bulk }}$ and $\mathrm{Ba}_{\text {excess }}$ to $\mathrm{Al}$ concentrations suggest no effects of continental detrital inputs on $\mathrm{Ba}$ accumulations in paleo-marine sediments (Fig. DR5A, B). For modern marine settings, clear correlations between accumulation rates of $\mathrm{Ba}_{\mathrm{excess}}$ and organic carbon were 
considered only observed in specific environments (e.g., the equatorial Pacific), challenging the use of $\mathrm{Ba}_{\text {excess }}$ as a widely reliable proxy for paleo-productivity (Schoepfer et al., 2015).. This case is also supported by no appreciable relationships of $\mathrm{Ba}_{\text {bulk }}$ or $\mathrm{Ba}_{\text {excess }}$ to TOC concentrations in the Neoproterozoic and Paleozoic ORMs, especially in samples with notably high $\mathrm{Ba}_{\text {bulk }}$ and $\mathrm{Ba}_{\text {excess }}$ concentrations (Fig. DR5C, D). In this context, we suggest that oceanic sulfate concentrations associated with ocean oxygenation levels may have played a first-order control on significant $\mathrm{Ba}_{\text {excess }}$ accumulations in the late Neoproterozoic and Paleozoic ORMs (cf. Wei and Algeo, 2020). The Precambrian oceans show inconspicuous $\mathrm{Ba}_{\text {excess }}$ enrichments in ORMs, presumably due to pervasive deep marine anoxia and limited sulfate concentrations (Canfield and Farquhar, 2009; Kah et al., 2004; Reinhard et al., 2013; Planavsky et al., 2014). However, some Paleoproterozoic ORMs (ca. $1.8 \mathrm{Ga}$ ) reveal relatively high $\mathrm{Ba}_{\text {excess, }}$ likely implying a transient increase in marine sulfate reservoir following the GOE (Poulton et al., 2004; Planavsky et al., 2012). The onset of significant $\mathrm{Ba}_{\text {excess }}$ enrichments in ORMs focuses on the late Neoproterozoic, and the early Cambrian (ca. $520 \mathrm{Ma}$ ) is marked by extreme $\mathrm{Ba}_{\text {excess }}$ enrichments in ORMs (Fig. 2A), corresponding to substantially elevated marine sulfate level during this period (Kah et al., 2004; Canfield and Farquhar, 2009; Algeo et al., 2015). High $\mathrm{Ba}_{\text {excess }}$ enrichments in ORMs persist through the Paleozoic, suggesting the protracted existence of a large dissolved Ba reservoir in the Paleozoic oceans. By contrast, no appreciable $\mathrm{Ba}_{\text {excess }}$ enrichments are recognized in the Mesozoic and Cenozoic ORMs, coincident with the inception of a resiliently oxygenated ocean and rise to the current marine sulfate concentration from the Mesozoic (Algeo et al., 2015; Lu et al., 2018). In each time interval, the ORMs can exhibit either high or low Beexcess contents (Fig. 2), 
likely controlled by short time-scale changes in marine redox state or depositional condition.

134 However, the secular trend in $\mathrm{Ba}_{\text {excess }}$ enrichments in ORMs throughout the Neoproterozoic and

135 Phanerozoic is closely related to temporal evolution of marine sulfate reservoir (Fig. 2, also see

136 Wei and Algeo, 2020). An increase in marine sulfate concentration accelerates the consumption

137 of dissolved $\mathrm{Ba}$ in the ocean via barite precipitation. Thus, the $\mathrm{Ba}_{\text {excess }}$ abundance in ORMs is

138 determined by the relative sizes of marine sulfate and Ba reservoirs. We further qualitatively

139 estimate changes in seawater $\mathrm{Ba}$ concentrations throughout the Neoproterozoic and

140 Phanerozoic based on the calculation of marine barite saturation (Fig. 3). The presumably

$141 \mathrm{BaSO}_{4}$-undersaturated conditions in the early Neoproterozoic oceans, demonstrated by non-

142 existent $\mathrm{Ba}_{\text {excess }}$ enrichments in ORMs, may have facilitated a notable $\mathrm{Ba}$ inventory to

143 accumulate from continental weathering or hydrothermal fluids. The marine dissolved Ba

144 reservoir during the early Neoproterozoic was likely three orders of magnitude larger than that

145 of the modern ocean (Fig. 3). The inception of $\mathrm{BaSO}_{4}$-supersaturated oceans from the late

146 Neoproterozoic led to an overall decrease in marine dissolved Ba concentrations; nevertheless,

147 the pervasive $\mathrm{BaSO}_{4}$-supersaturated conditions of the Paleozoic ocean required an oceanic $\mathrm{Ba}$

148 reservoir, at least, an order of magnitude larger than that of the modern ocean (Fig. 3). The

149 Mesozoic and Cenozoic oceans, characterized by $\mathrm{BaSO}_{4}$-undersaturated conditions, more

150 likely had low dissolved Ba concentrations, close to that of the modern ocean (Fig. 3).

151 Modern anoxic basins (e.g., Black Sea, Framvaren Fjord) consistently show notably higher

152 dissolved $\mathrm{Ba}$ concentrations in deep seawater $(280-460 \mathrm{nM})$, relative to the global pelagic

153 ocean $(<100 \mathrm{nM})$ (Falkner et al., 1993), due to remobilization of barites following sulfate

154 reduction in sediment pore waters (e.g., Schoepfer et al., 2015). In some oxygen-depleted 
continental margins (e.g., Peru margin), the recycled Ba can diffuse upward and re-precipitate as a diagenetic barite front across the sulfate-sulfide transition zone in the sediment piles (Torres et al., 1996). However, formation of this diagenetic barite front may have not been observed in ancient sedimentary rocks as a result of sediment compaction during the early diagenetic process. In other words, once the bottom waters have sufficient sulfate, dissolution of barite in the deeper sediment pile may not hamper the preservation of average high $\mathrm{Ba}_{\text {excess }}$ signals in ancient rocks, attributed to the formation of barite fronts in the upper sediment piles. Additionally, although increased continental or submarine weathering and hydrothermal inputs of Ba may have supplied additional Ba to a local depositional system or pelagic ocean (Dickens et al., 2003), such processes more likely occur on a several-million-year scale. Long-term evolution of the marine dissolved Ba reservoir throughout geological time cannot solely result from rapid changes in its source fluxes. Moreover, significant particulate $\mathrm{Ba}$ accumulation in ORMs originated from the late Ediacaran to the early Cambrian when chemical weathering intensity was relatively low before the colonization of land plants (e.g., Dahl and Arens, 2020). Accordingly, chemical weathering accelerated by land plants may not play a first-order control term global ocean redox evolution. Persistent $\mathrm{BaSO}_{4}$-undersaturated conditions in the

173 Precambrian oceans facilitated substantial accumulations of dissolved $\mathrm{Ba}$ in the seawater until marine sulfate concentrations approached a level where the saturation index was high enough for $\mathrm{BaSO}_{4}$ precipitation. Hence, no appreciable $\mathrm{Ba}_{\text {excess }}$ enrichments in ORMs suggest pervasive 
177 late Neoproterozoic to the Paleozoic substantially mark the global ocean oxygenation and

178 elevated marine dissolved sulfate concentrations. However, the persistence of a large marine

179 dissolved Ba reservoir through the Paleozoic, supported by ubiquitous $\mathrm{Ba}_{\text {excess }}$ enrichments in

180 ORMs and widespread bedded barite deposits in the Paleozoic (Fig. 2) (Jewell, 2000), indicates

181 that the NOE is relatively modest, and the background of the Paleozoic ocean oxygen level was

182 notably lower than that of the modern ocean. Traced by $\mathrm{Ba}_{\text {excess }}$ enrichments, the stabilization

183 of a resiliently oxygenated ocean should be much later than previously inferred by Mo, U, Re

184 enrichments in ORMs. A persistently and resiliently oxygenated ocean was more likely well-

185 established until the Mesozoic, which is consistent with the records of $\mathrm{I} / \mathrm{Ca}$ ratios in marine

186 carbonates ( $\mathrm{Lu}$ et al., 2018).

187 Conclusions

188 Built from the integration of $\mathrm{Ba}_{\text {excess }}$ concentrations in ORMs in this study, we indicate that

189 changes in size of the marine dissolved Ba reservoir are tightly related to the global ocean redox

190 state. In particular, significant $\mathrm{Ba}_{\text {excess }}$ enrichments in the Paleozoic ORMs require the

191 persistence of a more extensive marine dissolved Ba reservoir relative to the modern ocean.

192 This observation suggests that the global marine oxygenation level of the Paleozoic oceans was

193 substantially lower than that of the modern oceans, which hints a much later inception of the

194 persistently and resiliently oxygenated ocean until the Mesozoic.

195 Acknowledgments

196 This study was funded by the Strategic Priority Research Program(B) of the CAS

197 (XDB26000000) and the NSFC program (42002002, 41872002, 41661134048). We are grateful

198 to Editor Chris Clark, Prof. Thomas Algeo and an anonymous reviewer for their constructive 
reviews.

\section{References}

Algeo, T. J., and Li, C., 2020, Redox classification and calibration of redox thresholds in sedimentary systems: Geochimica Et Cosmochimica Acta, v. 287, p. 8-26.

Algeo, T.J., Luo, G.M., Song, H.Y., Lyons, T.W., Canfield, D.E., 2015. Reconstruction of secular variation in seawater sulfate concentrations. Biogeosciences 12, 2131-2151.

Bishop, J. K. B., 1988, The barite-opal-organic carbon association in oceanic particulate matter: Nature, v. 332, p. 341-343.

Bridgestock, L., Hsieh, Y.-T., Porcelli, D., Homoky, W. B., Bryan, A., and Henderson, G. M., 2018, Controls on the barium isotope compositions of marine sediments: Earth and Planetary Science Letters, v. 481, p. 101-110.

Canfield, D. E., 2005, The early history of atmospheric oxygen: Homage to Robert A. Garrels: Annual Review of Earth and Planetary Sciences, v. 33, no. 1, p. 1-36.

Canfield, D. E., and Farquhar, J., 2009, Animal evolution, bioturbation, and the sulfate concentration of the oceans: Proceedings of the National Academy of Sciences USA, v. 106, p. 8123-8127.

Crockford, P. W., Wing, B. A., Paytan, A., Hodgskiss, M. S. W., Mayfield, K. K., Hayles, J. A., Middleton, J. E., Ahm, A.-S. C., Johnston, D. T., Caxito, F., Uhlein, G., Halverson, G. P., Eickmann, B., Torres, M., and Horner, T. J., 2019, Barium-isotopic constraints on the origin of post-Marinoan barites: Earth and Planetary Science Letters, v. 519, p. 234-244.

Dahl, T. W., and Arens, S. K. M., 2020, The impacts of land plant evolution on Earth's climate and oxygenation state - An interdisciplinary review: Chemical Geology, v. 547, p. 119665. 
Dickens, G. R., Fewless, T., Thomas, E., Bralower, T. J., 2003, Excess barite accumulation during the Paleocene-Eocene Thermal Maximum: Massive input of dissolved barium from seafloor gas hydrate reservoirs: Geological Society of America Special Paper 369, v. 369, p. 11-23.

Dymond, J., Suess, E., and Lyle, M., 1992, Barium in deep-sea sediment: A geochemical proxy for paleoproductivity: Paleoceanography, v. 7, p. 163-181.

Falkner, K. K., klinkhammer, G. P., Bowers, T. S., Todd, J. F., Lewis, B. L., Landing, W. M., and Edmond, J. M., 1993, The behavior of barium in anoxic marine waters: Geochimica et Cosmochimica Acta, v. 57, no. 3, p. 537-554.

Holland, H. D., 2006, The oxygenation of the atmosphere and oceans: Philosophical Transactions: Biological Sciences, v. 361, no. 1470, p. 903-915.

Jewell, P. W., 2000, Bedded barite in the geologic record: in Marine Authigenesis: From Global to Microbial, SEPM Special Publication No.66, p. 147-161.

Kah, L. C., Lyons, T. W., and Frank, T. D., 2004, Low marine sulphate and protracted oxygenation of the Proterozoic biosphere: Nature, v. 431, no. 7010, p. 834-838.

Knoll, A. H., Nowak, M. A., 2017, The timetable of evolution: Science Advances, v. 3, p. e1603076.

Lu, W., Ridgwell, A., Thomas, E., Hardisty, D. S., Luo, G., Algeo, T. J., Saltzman, M. R., Gill, B. C., Shen, Y., Ling, H. F., Edwards, C. T., Whalen, M. T., Zhou, X., Gutchess, K. M., Jin, L., Rickaby, R. E. M., Jenkyns, H. C., Lyons, T. W., Lenton, T. M., Kump, L. R., and Lu, Z., 2018, Late inception of a resiliently oxygenated upper ocean: Science, v. 361, no. 6398, p. 174-177. 
Lyons, T. W., Reinhard, C. T., and Planavsky, N. J., 2014, The rise of oxygen in Earth's early ocean and atmosphere: Nature, v. 506, no. 7488 , p. 307-315.

Martinez-Ruiz, F., Paytan, A., Gonzalez-Muñoz, M. T., Jroundi, F., Abad, M. M., Lam, P. J., Bishop, J. K. B., Horner, T. J., Morton, P. L., and Kastner, M., 2019, Barite formation in the ocean: Origin of amorphous and crystalline precipitates: Chemical Geology, v. 511, p. $441-451$.

Och, L. M., and Shields-Zhou, G. A., 2012, The Neoproterozoic oxygenation event: Environmental perturbations and biogeochemical cycling: Earth-Science Reviews, v. 110, no. $1-4$, p. $26-57$.

Partin, C. A., Bekker, A., Planavsky, N. J., Scott, C. T., Gill, B. C., Li, C., Podkovyrov, V., Maslov, A., Konhauser, K. O., Lalonde, S. V., Love, G. D., Poulton, S. W., and Lyons, T. W., 2013, Large-scale fluctuations in Precambrian atmospheric and oceanic oxygen levels from the record of U in shales: Earth and Planetary Science Letters, v. 369-370, p. 284293.

Paytan, A., and Griffith, E. M., 2007, Marine barite: Recorder of variations in ocean export productivity: Deep Sea Research Part II: Topical Studies in Oceanography, v. 54, no. 5-7, p. $687-705$.

Planavsky, N. J., Bekker, A., Hofmann, A., Owens, J. D., and Lyons, T. W., 2012, Sulfur record of rising and falling marine oxygen and sulfate levels during the Lomagundi event: Proceedings of the National Academy of Sciences USA, v. 109, no. 45, p. 18300-18305.

Planavsky, N. J., Reinhard, C. T., Wang, X., Thomson, D., McGoldrick, P., Rainbird, R. H., Johnson, T., Fischer, W. W., and Lyons, T. W., 2014, Low mid-Proterozoic atmospheric 
oxygen levels and the delayed rise of animals: Science, v. 346, no. 6209, p. 635-638.

Poulton, S. W., Fralick, P. W., and Canfield, D. E., 2004, The transition to a sulphidic ocean approximately 1.84 billion years ago: Nature, v. 431, no. 7005 , p. 173-177.

Reinhard, C. T., Planavsky, N. J., Robbins, L. J., Partin, C. A., Gill, B. C., Lalonde, S. V., Bekker, A., Konhauser, K. O., and Lyons, T. W., 2013, Proterozoic ocean redox and biogeochemical stasis: Proceedings of the National Academy of Sciences USA, v. 110, no. 14, p. 5357-5362.

Robbins, L. J., Lalonde, S. V., Planaysky, N. J., Partin, C. A., Reinhard, C. T., Kendall, B., Scott, C., Hardisty, D. S., Gill, B. C., Alessi, D. S., Dupont, C. L., Saito, M. A., Crowe, S. A., Poulton, S. W., Bekker, A., Lyons, T. W., and Konhauser, K. O., 2016, Trace elements at the intersection of marine biological and geochemical evolution: Earth-Science Reviews, v. 163 , p. $323-348$.

Rudnick, R.L., Gao, S., 2014, Composition of the continental crust. In: Treatise on Geochemistry, second edition, vol.4, pp.1-51.

Schoepfer, S. D., Shen, J., Wei, H., Tyson, R. V., Ingall, E., and Algeo, T. J., 2015, Total organic carbon, organic phosphorus, and biogenic barium fluxes as proxies for paleomarine productivity: Earth-Science Reviews, v. 149, p. 23-52.

Scott, C., Lyons, T. W., Bekker, A., Shen, Y., Poulton, S. W., Chu, X., and Anbar, A. D., 2008, Tracing the stepwise oxygenation of the Proterozoic ocean: Nature, v. 452, no. 7186, p. 456-459.

Sheen, A. I., Kendall, B., Reinhard, C. T., Creaser, R. A., Lyons, T. W., Bekker, A., Poulton, S. W., and Anbar, A. D., 2018, A model for the oceanic mass balance of rhenium and 

Acta, v. 227, p. 75-95.

Torres, M. E., Brumsack, H. J., Bohrmann, G., and Emeis, K. C., 1996, Barite fronts in continental margin sediments: a new look at barium remobilization in the zone of sulfate reduction and formation of heavy barites in diagenetic fronts: Chemical Geology, v. 127, no. 1-3, p. 125-139.

Tostevin, R., and Mills, B. J. W., 2020, Reconciling proxy records and models of Earth's oxygenation during the Neoproterozoic and Palaeozoic: Interface Focus, v. 10, no. 4, p. 287, p. 367-390. 
Fig. 1. Compilations of Mo, U, and Re concentrations in ORMs, corresponding to the evolution of Earth's atmospheric oxygen content and key biological innovation events through the Precambrian. The red lines in (A), (B), (C) denote the average values for Archaean, early Proterozoic (only for B), mid-Proterozoic and Neoproterozoic-Phanerozoic data (data from Scott et al., 2008; Partin et al., 2013; Sheen et al., 2018). (D) is modified from Lyons et al. (2014), Knoll and Nowak (2017), and references therein.

Fig. 2. Temporal trends in $\mathrm{Ba}_{\text {excess }}$ enrichment in ORMs (data sources are presented in the supplementary table). The blue circles denote the data before the Neoproterozoic; the gray circles denote the data from the Neoproterozoic to Paleozoic; the yellow circles denote the data in Mesozoic and Cenozoic. The brown bars in indicate the temporal distribution of bedded barite deposits (Jewell, 2000). The evolution of marine sulfate concentrations (with $2 \sigma$ (2015). concentrations in modern ocean. The white star indicates the Ba concentration of modern Black Sea deep water ( $\mathrm{SO}_{4}$ concentration is zero). The dashed areas represent the ranges of 


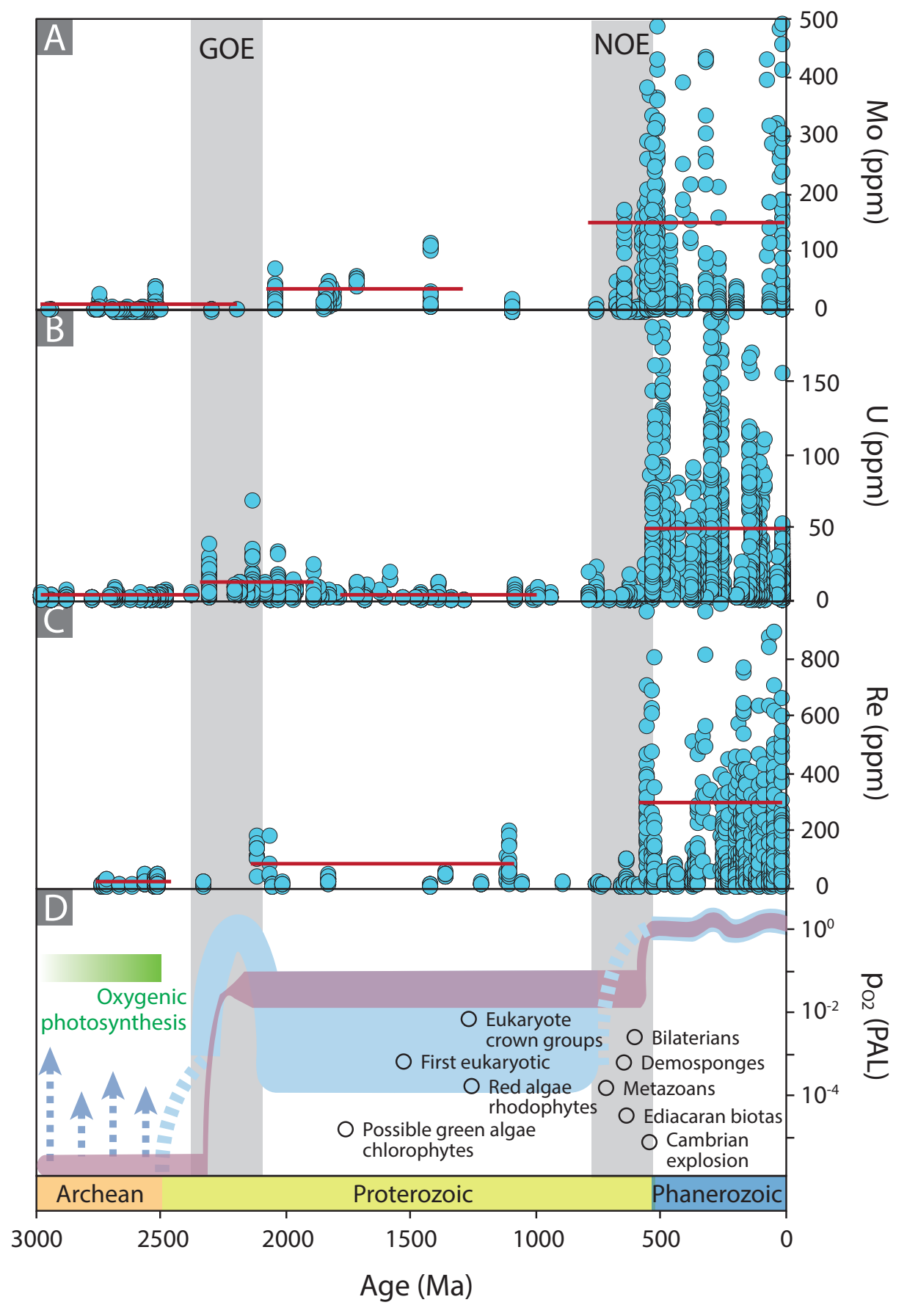




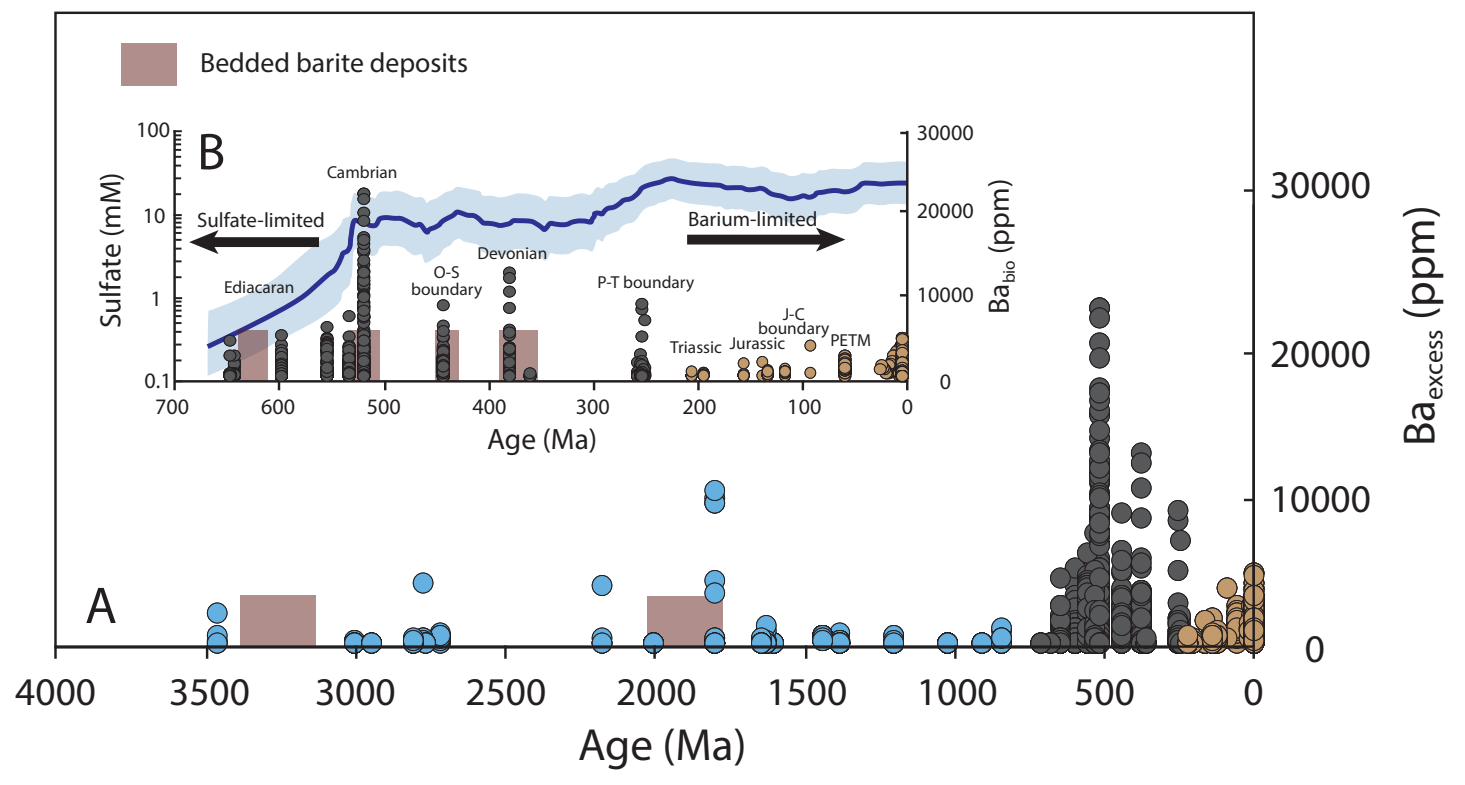




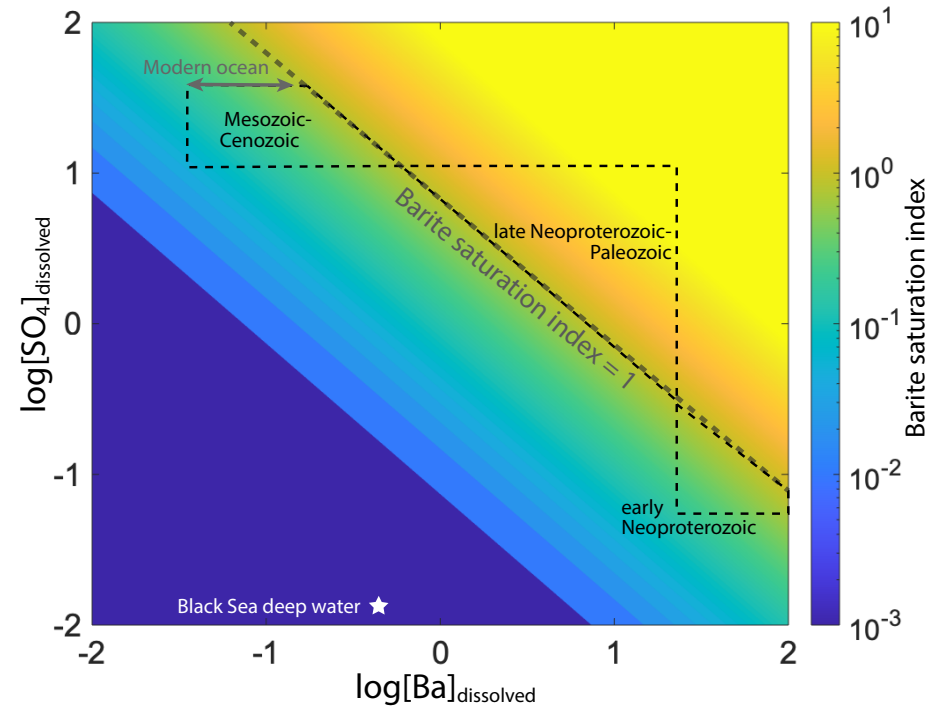




\section{Supplementary materials for}

\section{Revisiting stepwise ocean oxygenation with authigenic Ba enrichments in marine}

\section{mudrocks}

Guang-Yi Wei ${ }^{1 *}$, Hong-Fei Ling ${ }^{1}$, Simon V. Hohl ${ }^{2}$, Graham A. Shields ${ }^{3}$, Tao Yang ${ }^{1}$, Yi-Bo

$$
\text { Lin }^{1} \text {, Feifei Zhang }{ }^{1}
$$

${ }^{I}$ State Key Laboratory for Mineral Deposits Research, School of Earth Sciences and Engineering, Nanjing University, Nanjing 210023, China

${ }^{2}$ State Key Laboratory of Marine Geology, School of Ocean and Earth Sciences, Tongji University, Shanghai 200092, China

${ }^{3}$ Department of Earth Sciences, University College London, Gower Street, London WC1E 6BT, U.K.

*Email: G.-Y. Wei (guangyiwei@nju.edu.cn)

\section{DR1. Distinctions of different types of barite in marine sediments}

Scanning electron microscope (SEM) images of barite crystals separated from the different depositional environments exhibit varying morphologies and sizes (shown in Fig. DR1 from Paytan et al., 2002). Marine barite crystals deposited from water column are characterized by ellipsoidal in shape and small size $(<5-8 \mu \mathrm{m})$. Hydrothermal barite crystals are generally precipitated as cross-cutting tabular crystals and form rosettes with nobaly large crystal size $(20-70 \mu \mathrm{m})$. Diagenetic barite crystals are larger $(20-700 \mu \mathrm{m})$, flat, tabular-shaped and presented as barite beds in the sediments.

We check the SEM images of the early Cambrian black shales in South China with significant Ba enrichments (Figs. DR2,3). The particulate Ba in the early Cambrian black shales is presented as aggregates of barite with relative small crystal size and elliptical to sub- 
spherical structures. Despite the potential diagenetic process during the black shale burial, morphological observations suggest a marine authigenic origin for the barites in the early Cambrian black shales. We also select those black shale and mudstone samples that are not altered by hydrothermal fluids based on the descriptions in published literature.

\section{DR2. Material and methods}

New Ba concentration data were obtained from two early Cambrian organic-rich mudrock successions. Cherty shales, black shales and mudstones were collected from the Daotuo Drill core and the Yanjia section that were the same batches of samples in Wei et al. (2017) and (2020). These two sections are interpreted to have been deposited from the terminal Ediacaran to the lower Cambrian in a mid-depth margin-slope (Daotuo) to a deeper basin environment (Yanjia) on a continental margin. In order to avoid the contamination of $\mathrm{Ba}$ from authigenic carbonate, only bulk samples that have relatively low Ca concentrations $(<$ $3 \%)$ were selected and ground into 200 mesh powders and then oven-dried at $60{ }^{\circ} \mathrm{C}$ for $\mathrm{Ba}$ concentration analysis. Approximately $50 \mathrm{mg}$ of sample powder was weighed, then fully digested using distilled $\mathrm{HF}+\mathrm{HNO}_{3}+\mathrm{HCl}$ acids. The solutions were dried and re-dissolved in $6 \mathrm{~N} \mathrm{HCl}$ in preparation for element and isotope analyses. The Ba concentrations were measured on a Thermo Finnigan Element XR ICP-MS at the State Key Laboratory for Mineral Deposits Research, Nanjing University and the Yale Metal Geochemistry Center (YMGC), Yale University. The IAPSO seawater and USGS BHVO-2 standards were used to monitor the long-term reproducibility of the measurements (better than 5\% in this study). The $\mathrm{Ba}_{\text {excess }}$ data, along with published geochemical data in the Daotuo drillcore and Yanjia section are presented in Fig. DR4. 


\section{DR3. Compilations of Ba concentrations in shales and mudstones}

New analyzed and integrated data were presented in supplementary table with brief introduction and reference list in it.

\section{DR4. Calculation of barite saturation index}

The saturation index of barites in the ocean was calculated in terms of the activity product of free $\mathrm{Ba}$ and $\mathrm{SO}_{4}$ ions in the aqueous solution,

$$
\begin{gathered}
\mathrm{Kd}=a_{B a} \cdot a_{S O 4} \\
a_{i}=\Gamma_{i}(T, P) \cdot m_{i}=\gamma_{i} f_{i} \cdot m_{i}
\end{gathered}
$$

where $\mathrm{Kd}$ is thermodynamic solubility product, $\mathrm{a}_{\mathrm{i}}$ is the activity product of free ions, $\mathrm{m}_{\mathrm{i}}$ is the product of the total molality, $\gamma_{\mathrm{i}}$ and $\Gamma_{\mathrm{i}}$ are the simple and apparent activity coefficients, respectively, which can be expressed as a function of temperature and pressure. Then the completed equation for barite saturation in the seawater can be defined as,

$$
\operatorname{Kd}(\mathrm{T}, \mathrm{P})=\left(\gamma_{B a} \cdot f_{B a} \cdot m_{B a}\right) \cdot\left(\gamma_{S O 4} \cdot f_{S O 4} \cdot m_{S O 4}\right)
$$

In this study, we use the values of $\mathrm{Kd}, \gamma_{\mathrm{Ba}}, \gamma_{\mathrm{SO} 4}, \mathrm{f}_{\mathrm{Ba}}, \mathrm{f}_{\mathrm{SO} 4}$ as $1.1 \times 10^{-10}, 0.24,0.17,0.93,0.39$, respectively, assuming a temperature of $25^{\circ} \mathrm{C}$ and a pressure of one atm for calculations (Church and Wolgemuth, 1972).

\section{References}

Church, T. M., and Wolgemuth, K., 1972, Marine barite saturation: Earth and Planetary Science Letters, v. 15 , no. 1, p. 35-44.

Paytan, A., Mearon, S., Cobb, K., and Kastner, M., 2002, Origin of marine barite deposits: Sr and $\mathrm{S}$ isotope characterization: Geology, v. 30, no. 8, p. 747-750. 
Wei, G.-Y., Planavsky, N. J., Tarhan, L. G., He, T., Wang, D., Shields, G. A., Wei, W., and Ling, H.-F., 2020, Highly dynamic marine redox state through the Cambrian explosion highlighted by authigenic $\delta^{238} \mathrm{U}$ records: Earth and Planetary Science Letters, v. 544, p. 116361. 

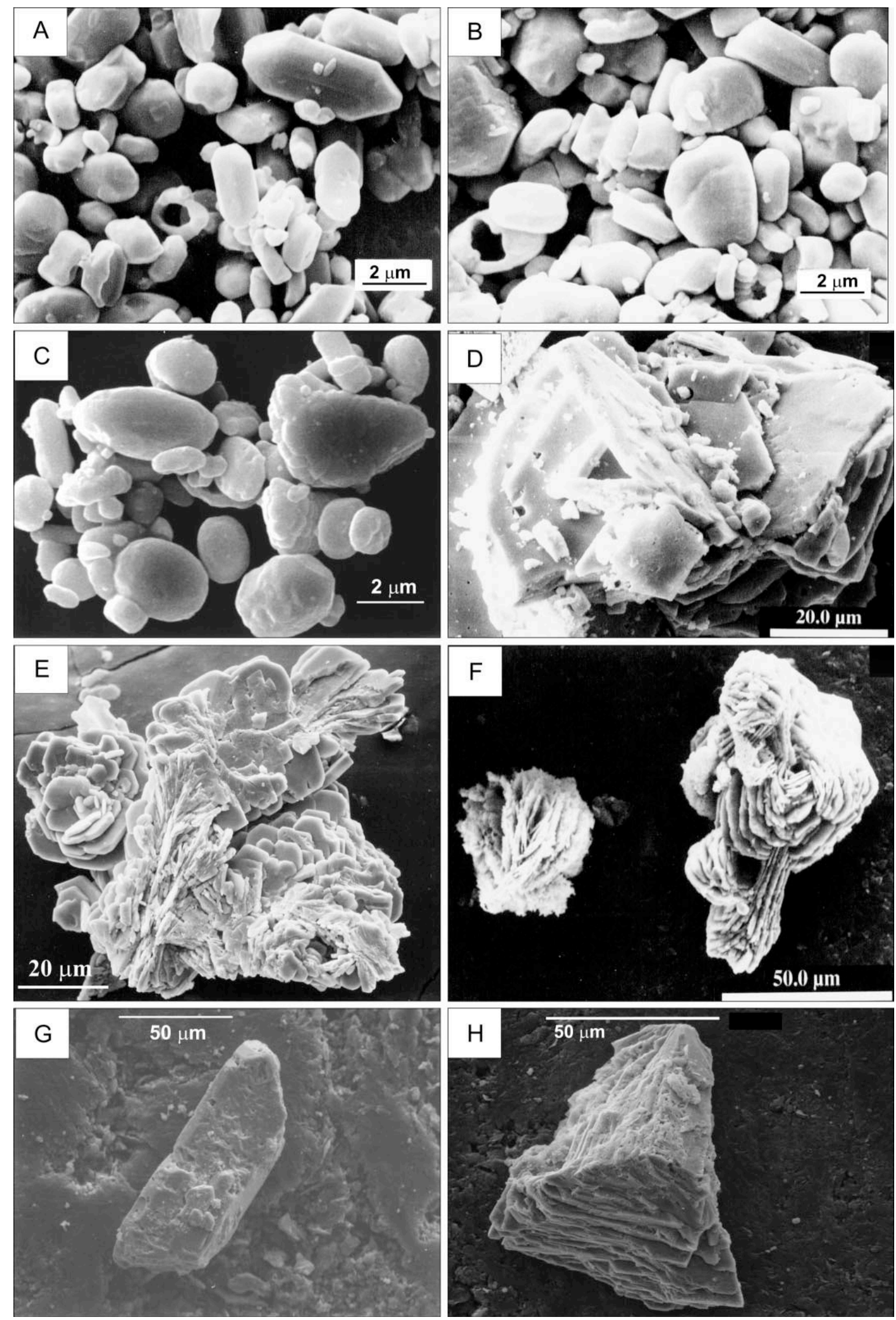

Fig. DR1. SEM (scanning electron microscopy) photographs of barite crystals from different modern oceanic settings (from Paytan et al., 2002). (A) (B) (C) are authigenic barites in marine sediments. (D) (E) (F) are hydrothermal barites near the hydrothermal chimneys. $(\mathrm{G})(\mathrm{H})$ are diagenetic barites in marine sediments. 

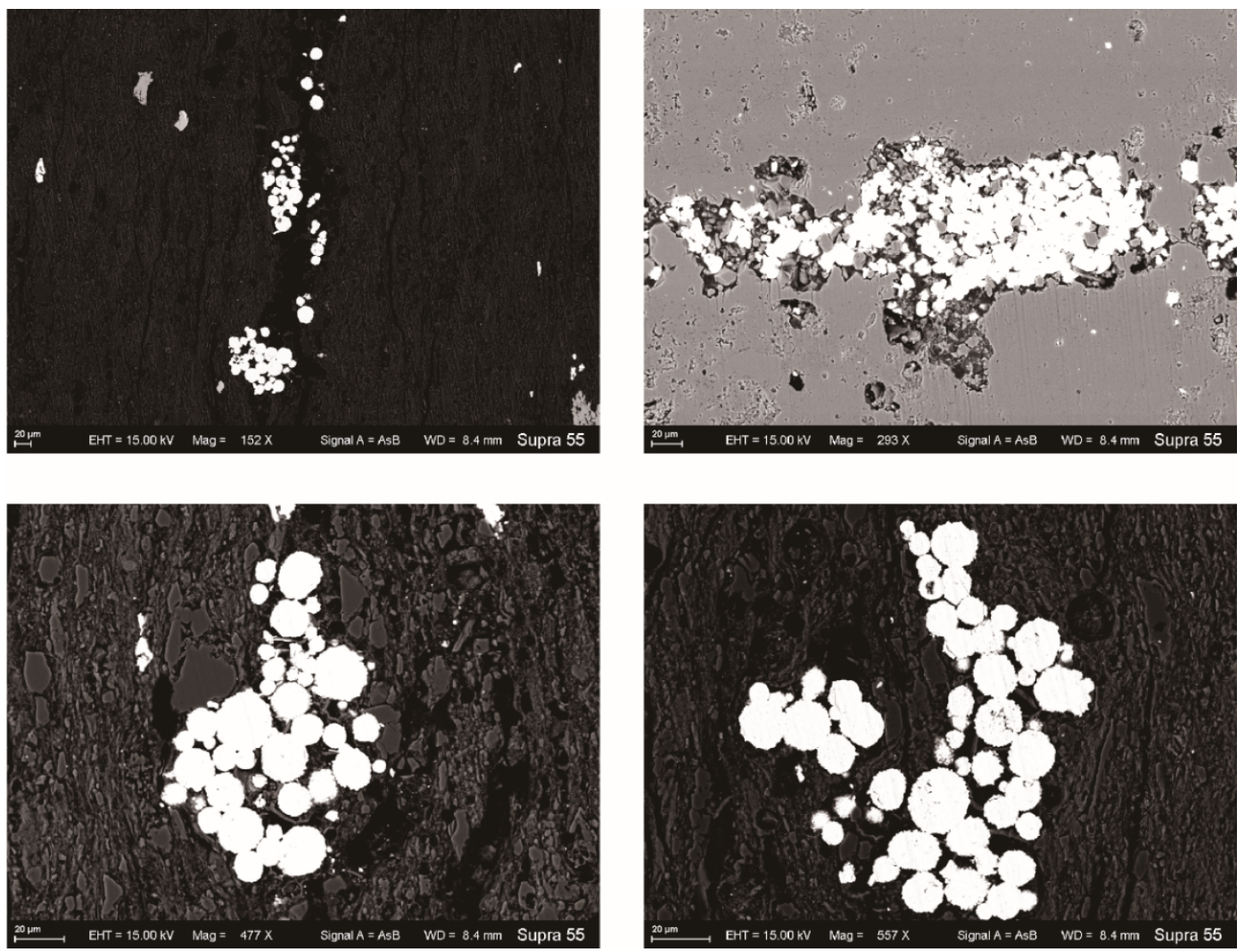

Fig. DR2. SEM (scanning electron microscopy) photographs of barite particles for black shales in the lower Cambrian in this study.
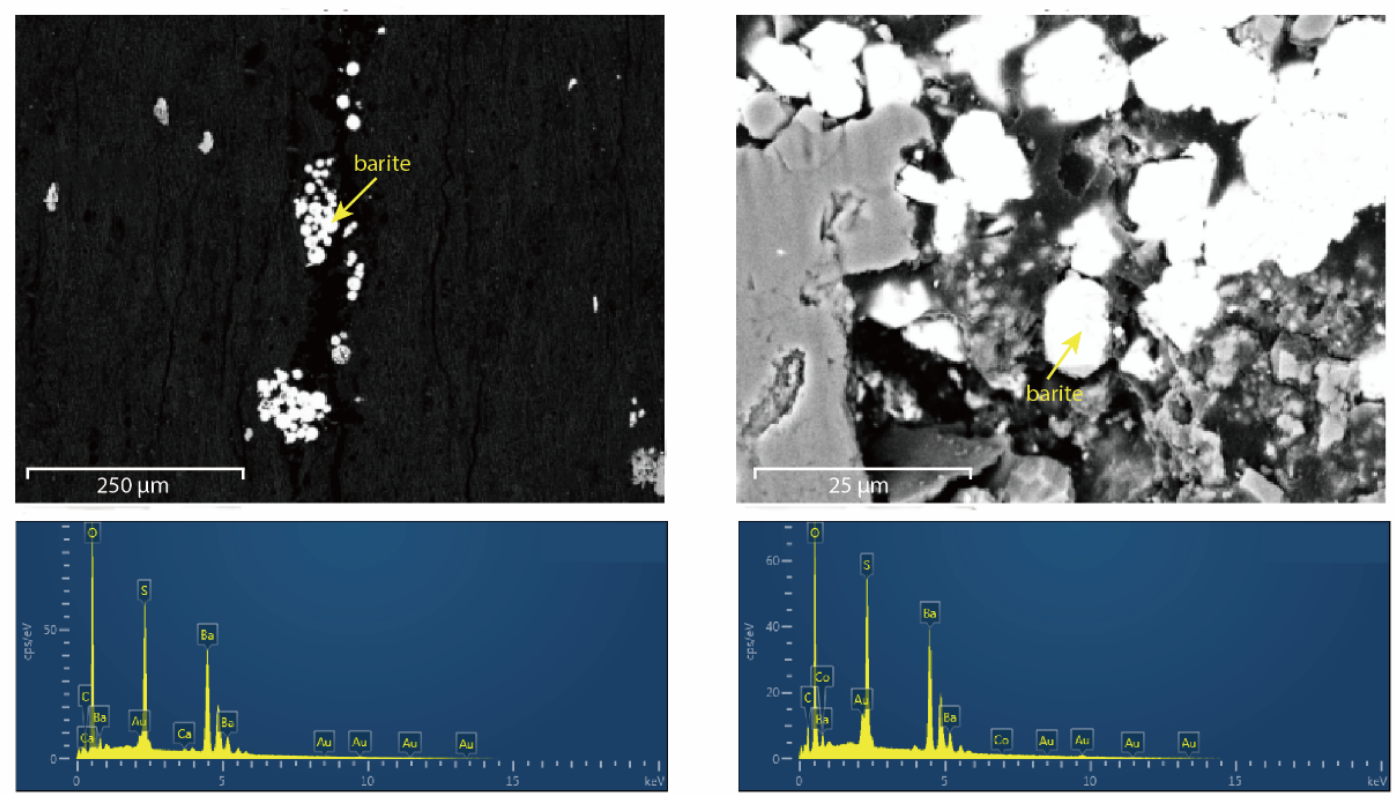

Fig. DR3. SEM photographs of barite particles for representative black shales in the lower Cambria. The barites in the samples are identified as peaks of $\mathrm{O}, \mathrm{S}$ and $\mathrm{Ba}$, using EDS (energy-dispersive spectrometry). 

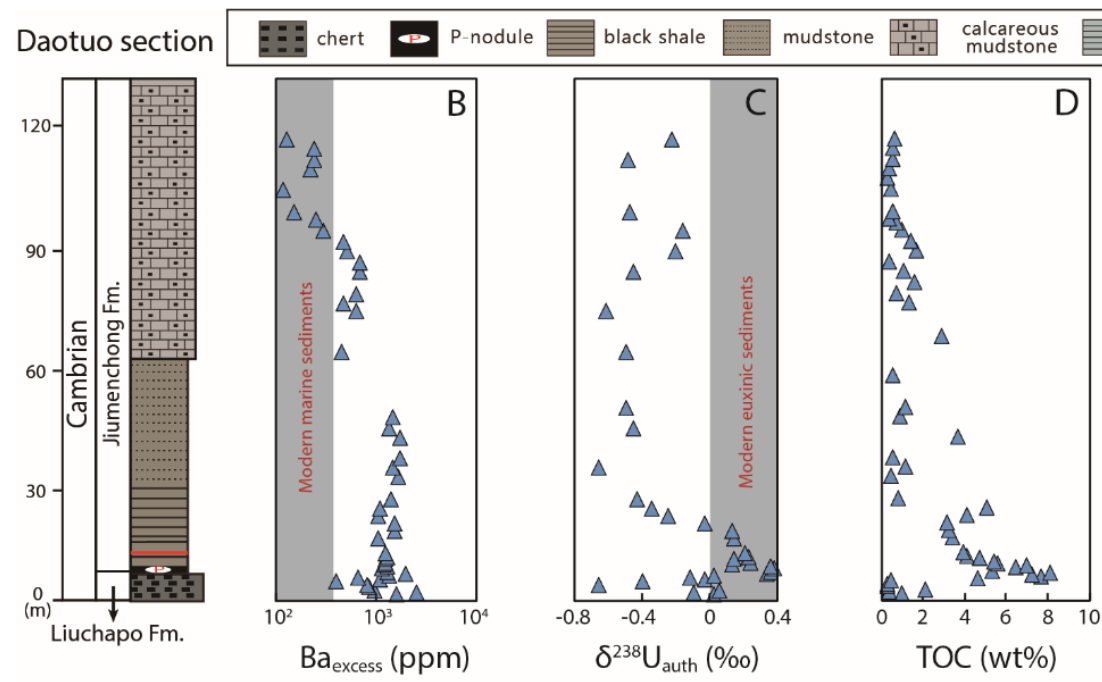

siliceous shale polymetallic layer

Yanjia section
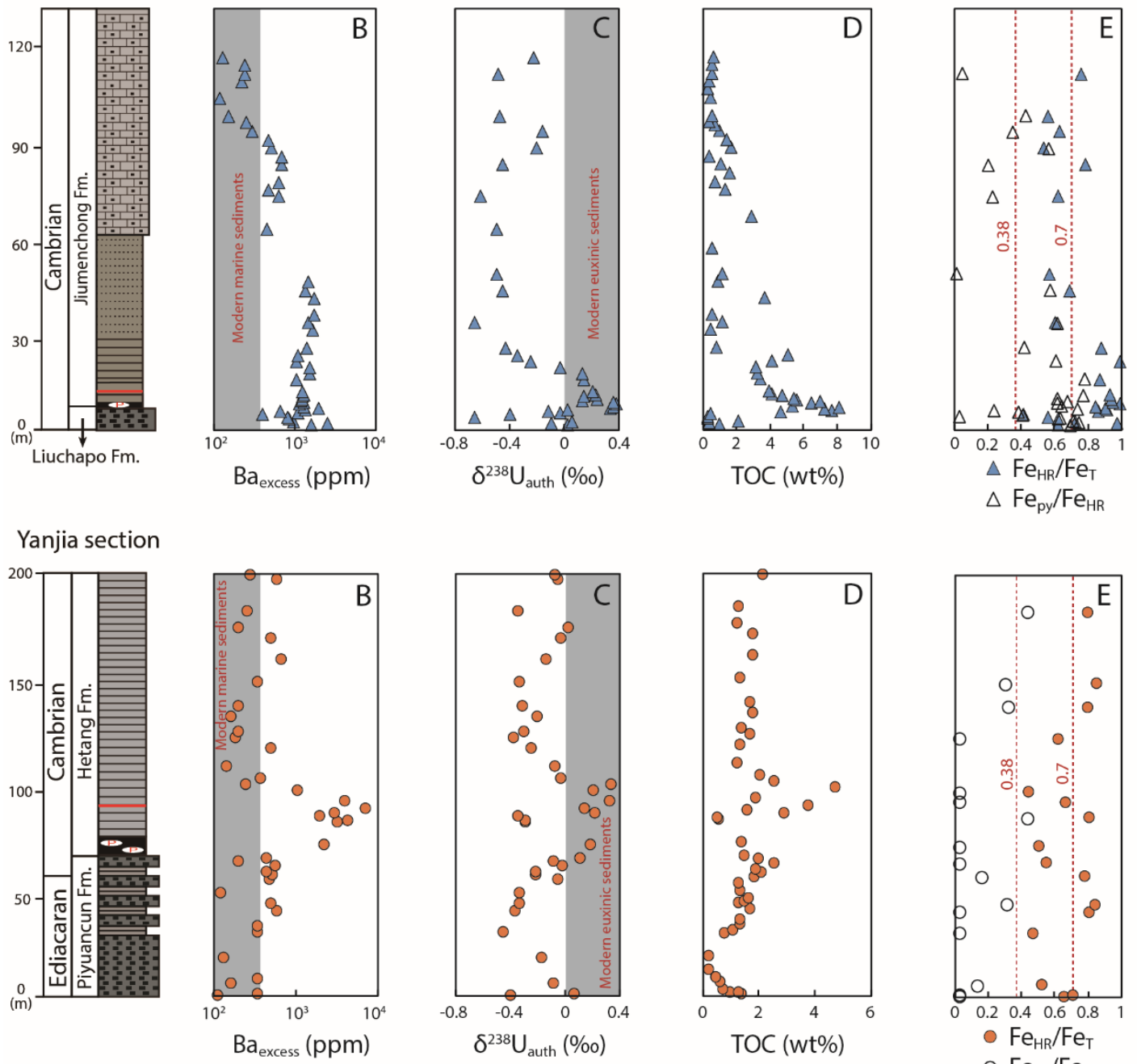

Fig. DR4. Geochemical profiles of the Daotuo drillcore and Yanjia section, including Baexcess concentrations (this study), and U isotope, TOC, Fe speciation data (from Wei et al., 2020). 

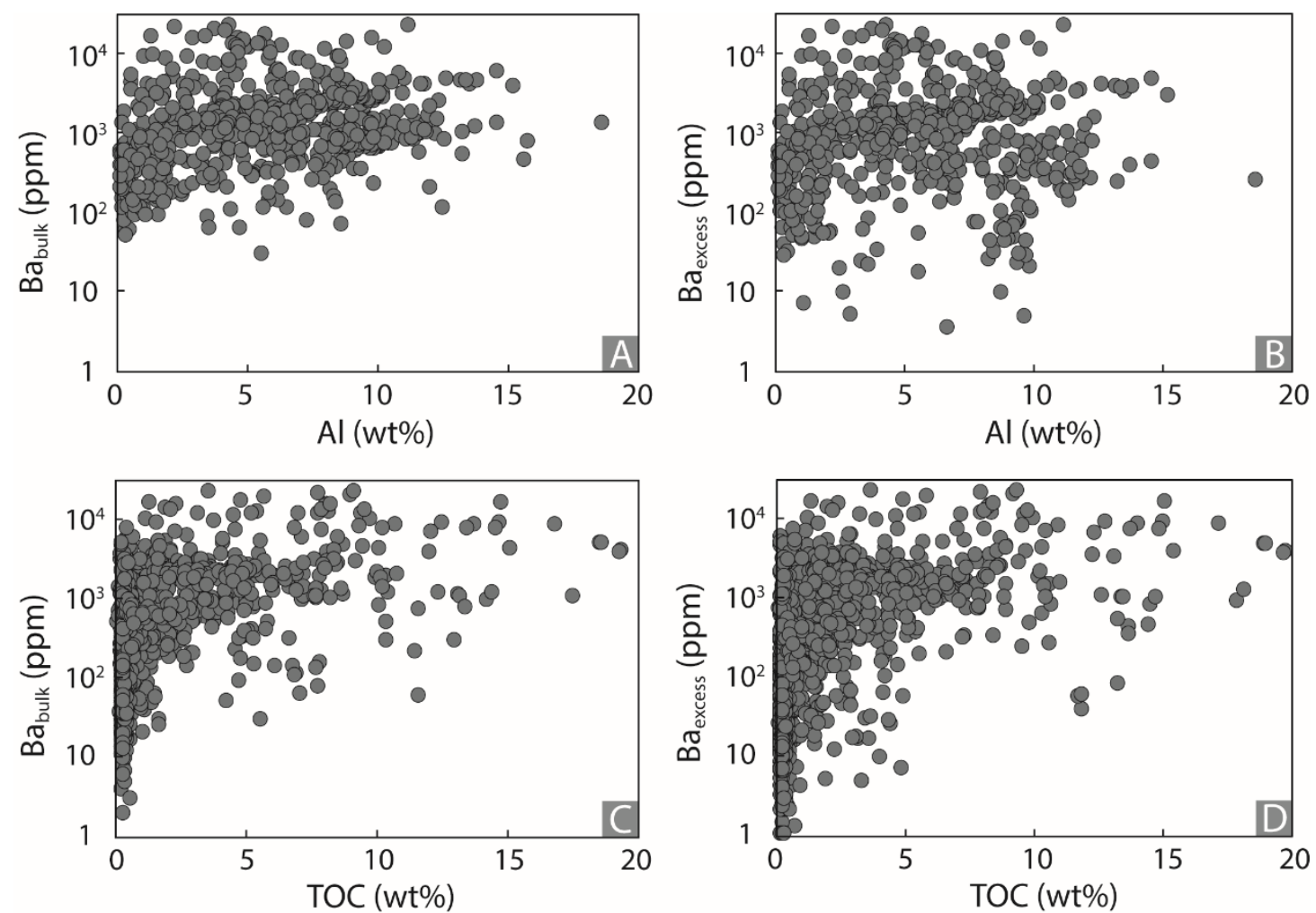

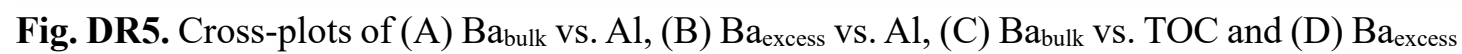
vs. TOC contents for the collected Neoproterozoic and Paleozoic samples. 